\title{
The Warranty of Habitability Debate: A California Case Study
}

\begin{abstract}
Allan David Heskin $\dagger$
The effects of the emerging warranty of habitability doctrine on the quality and supply of low-income housing are not yet clear. This Article reports the results of a case study recently undertaken in southern California on the impact of the warranty doctrine. It suggests that the doctrine is beginning to have its intended consequences, even though it continues to face formidable problems of implementation.
\end{abstract}

Since 1969, the doctrine of warranty of habitability has been adopted by appellate courts across the country. ${ }^{1}$ The California Supreme Court joined its sister courts in 1974 with Green v. Superior Court. ${ }^{2}$ The adoption of the warranty of habitability has brought contract principles to the landlordtenant relationship. The primary holding of these cases has been that a material breach of the landlord's responsibility to keep the leased premises in habitable repair diminishes the tenant's obligation to pay rent. Green held that a breach of the warranty of habitability that "materially affects health and safety" 3 releases the tenant from the contractual obligation to pay rent, leaving the tenant responsible only for the "reasonable rental value" of the uninhabitable premises. ${ }^{4}$

$\dagger$ B.S. 1960, University of California, Berkeley; LL.B. 1963, Boalt Hall School of Law; Ph.D. 1975, University of Washington; Assistant Professor of Architecture and Urban Planning, University of California, Los Angeles. Funding for this study was provided by the University of California, Los Angeles Academic Senate Research Grant Program. Research assistance was provided by Jeffery Dack, Jennifer Spiegel, and Kenichi Tokunaga.

1. Javins v. First Nat'l Realty Corp., 428 F.2d 1071 (D.C. Cir.), cert. denied, 400 U.S. 925 (1970); LeClair v. Woodward, 6 Conn. Cir. Ct. 727, 316 A.2d 791 (1970); Givens v. Gray, 126 Ga. App. 309, 190 S.E.2d 607 (1972); Lemle v. Breeden, 51 Haw. 426, 462 P.2d 470 (1969); Jack Spring, Inc. v. Little, 50 Ill. 2d 351, 280 N.E.2d 208 (1972); Old Town Dev. Co. v. Langford, 349 N.E.2d 744 (Ind. Ct. App. 1976); Mease v. Fox, 200 N.W.2d 791 (Iowa 1972); Steele v. Latimer, 214 Kan. 329, 521 P.2d 304 (1974); Boston Hous. Auth. v. Hemingway, 363 Mass. 184, 293 N.E.2d 831 (1973); Rome v. Walker, 38 Mich. App. 458, 196 N.W.2d 850 (1972); Fritz v. Warthen, 298 Minn. 54, 213 N.W.2d 339 (1973); King v. Moorehead, 495 S.W.2d 65 (Mo. Ct. App. 1973); Kline v. Burns, 111 N.H. 87, 276 A.2d 248 (1971); Marini v. Ireland, 56 N.J. 130, 265 A.2d 526 (1970); Commonwealth v. Monumental Properties, Inc., 459 Pa. 450, 329 A.2d 812 (1974); Foisy v. Wyman, 83 Wash. 2d 22, 515 P.2d 160 (1973); see also Pines v. Perssion, 14 Wis. 2d 590, 111 N.W.2d 409 (1961). But see Posnanski v. Hood, 46 Wis. 2d 172, 174 N.W.2d 528 (1970).

2. 10 Cal. 3d 616, 517 P.2d 1168, 111 Cal. Rptr. 704 (1974).

3. Id. at 637,517 P.2d at 1183,111 Cal. Rptr. at 719 .

4. Id. at 629, 517 P.2d at 1176, 111 Cal. Rptr. at 712 (citing Henson v. Delis, 26 Cal. App. 3d 62, 70, 102 Cal. Rptr. 661, 666 (1st Dist. 1972)). 
The adoption of the warranty of habitability has been hailed as a victory for tenants and low-income housing and cursed as another contributor to housing decline. Proponents of the adoption of the warranty have claimed that the reform will help preserve low-cost private housing, ${ }^{5}$ improve the legal status of tenants, ${ }^{6}$ broaden code enforcement, ${ }^{7}$ induce landlords to make repairs, ${ }^{8}$ and reduce the number of unlawful detainer actions. ${ }^{9}$ They believe that the law will result in some housing improvements without rent increases, ${ }^{10}$ increase the tenant's leverage in out-of-court settlements and lead to the creation of tenant unions. ${ }^{11}$

Opponents of the warranty anticipate that it will diminish the landlord's return from the leased property and subsequently make repairs impossible. ${ }^{12}$ In this view, the warranty will lead to higher rents, ${ }^{13}$ overcrowding, abandonment, less investment in low-rent housing, and constriction of the supply of low-cost housing. ${ }^{14}$ Critics also believe that tenants will use the warranty to harrass landlords or that lawyers will abuse the opportunity to conduct protracted litigation. ${ }^{15}$

A third group, citing a recent study of the unlawful detainer process in San Francisco, argues that the warranty of habitability will have little positive or negative effect on housing or landlord-tenant relationships. ${ }^{16} \mathrm{The}$ authors of the San Francisco study interviewed landlord and tenant attorneys in the Bay Area and examined the San Francisco Municipal Court docket for six months of 1974. They concluded that low-income tenants do not receive the legal advice necessary for them to make use of the warranty: Green appeared to be "a classic example of a 'progressive' judicial move remaining unknown and inaccessible to the very people it was intended to assist." 17

5. McElhaney, Retaliatory Evictions: Landlords, Tenants and Law Reform, 29 MD. L. REV. 193, 226 (1969).

6. Note, Leases and the Illegal Contract Theory-Judicial Reinforcement of the Housing Code, 56 GEo. L.J. 920,928 (1968) [hereinafter cited as Leases].

7. Moskovitz, The Implied Warranty of Habitability: A New Doctrine Raising New Issues, 62 CALIF. L. REv. 1444, 1503-04 (1974).

8. Daniels, Judicial and Legislative Remedies for Substandard Housing: Landlord-Tenant Law Reform in the District of Columbia, 59 GEo. L.J. 909, 925 (1971).

9. Comment, Green v. Superior Court: A New Remedy for the California Tenant, 5 Golden GATE L. REv. 145, 157 (1974).

10. P. Weitzman, An Economic Analysis of the Impact of Repair and Deduct Legislation (November 1977) (unpublished article available from Nat'l Social Science \& Law Project, Inc., 1990 M St., N.W., Suite 610, Washington, D.C. 20036).

11. Moskovitz, supra note 7 , at 1504 .

12. Leases, supra note 6, at 937.

13. See Lyman, A Response to ULTRA-The Uniform Landlord Tenant Relationshlp $A c t, 37$ J. Prop. Management 149, 159 (1972).

14. Leases, supra note 6, at 937.

15. Meyers, The Covenant of Habitability and the American Law Institute, 27 STAN. L. REV. 879, 888 (1975).

16. Note, The Great Green Hope: The Implied Warranty of Habitability in Practice, 28 STAN. L. REv. 729 (1976) [hereinafter cited as Green Hope].

17. Id. at 776-77. Their conclusions were based primarily on the small amount of activity reflected in the court docket. 
Each of these three positions makes untested assumptions about the condition of housing, the vitality of the real estate market, the situation of low-income tenants and their landlords, the diffusion of law reform, and the roles of lawyers and courts. The proponents of Green believe that the warranty can be effective because they assume that low-income housing is economically repairable. They anticipate few problems in the diffusion of law reform and great potential in tenant initiative. Critics of the warranty assume a non-renewable housing stock and a fragile real estate market like the model derived from studies of central cities in the Northeast. They also assume tenants and lawyers will exploit the law toward their short term interests, to the detriment of the landlord and the future of low-income housing. Those who believe that the warranty will have little practical impact either way assume that in-court activity is a good indicator of knowledge and use of the warranty. They also assume that low income housing is in such disrepair that most tenants who are evicted could legitimately plead the warranty in defense of their case.

This Article presents the results of a case study on the impact of Green in a low-income area of southern California. It is not intended to lead to a conclusive resolution of the debate between those who favor and those who oppose Green. Its primary purpose is to add the texture of experience to the theoretical arguments already underway, so that more sophisticated and sharpened hypotheses might be formulated for future study. But while it must be stressed that a case study is limited in scope and may not represent national or regional patterns, the results of the study may be profitably used to test the assumptions made by those who currently lead the debate over Green's merits. Its findings leave none of the current positions intact. The arguments of Green's proponents and of those who believe the case will have little or no effect emerge muted. The arguments of Green's opponents seem to be refuted.

Following the presentation of the methodology and base data of the study, the various arguments put forward by the three positions will be examined. The nature of the impacted low-income housing market, including the type and condition of the structures and ownership patterns will be described, and the claims of the proponents and opponents of Green regarding the likelihood of obtaining the repair of property, the impact on rents and the abuse of the doctrime will be evaluated. Next, the methods and conclusions of this and of the San Francisco study will be compared and the problems of implementing law reforms will be explored. These problems include those with the court, the lawyers, the law, the clients, and tenant union formation. The Article concludes with a statement of the hypotheses supported by the study's major findings. 


\section{I \\ METHODOLOGY AND BASE DATA}

It is assumed in this study that the information contained in the files of a legal services office is a better indicator of Green activity than the information contained in a court docket. It is believed that legal services attorneys are the primary medium connecting the warranty with the tenant, and that like other lawyers, they do much of their work out-of-court. Starting with these assumptions, a legal services office in southern California was selected as the base of the study becase of its regional reputation for knowledgeable and aggressive work in the housing field. ${ }^{18}$ This office had a defined low-income community within its program area. The community was serviced by a branch of the municipal court. The community (referred to as the "study area" to protect the confidentiality of the legal services clients) was two-thirds of the legal services office service area and nearly all of the jurisdiction of the branch of the municipal court. Two housing code enforcement agencies, the City Building and Safety Division and the County Health Department, served the study area and inspected parcels of property of interest to this study.

\section{A. Study Design}

A study design was formulated for the period of June 1975 through May 1976. It began with a review of the legal services files. All landlordtenant cases involving property in the study area were identified and analyzed, with particular attention given to files which included references to problems with the condition of the leased property. ${ }^{19}$ The court docket and files were then examined and cross-referenced with the legal services files. Attempts were made to interview tenants who had complained about conditions (hereinafter referred to as "warranty tenants") and their landlords to

18. Members of the staff of the Regional Back-Up Center, the Western Center on Law and Poverty, initially suggested this office. Later discussions with other prominent legal services attorneys and others knowledgeable about housing advocacy in the region confirmed the initial suggestion.

19. There were 48 tenants with complaints about conditions. Not all of the files were complete, so the study contains only partial data on several points. The age of the tenants was: Under $20,9 \%$; 20 to $29,50 \%$; 30 to $39,20 \%$; 40 to $59,9 \%$; 60 to $69,9 \%$; 70 and over, $4 \%$ ( $N=46)$.

The racial composition was: 46\% Anglo; 46\% Latino; 4\% Black; 2\% Native American; 2\% Samoan $(\mathrm{N}=46)$.

For the source of income see Table 7 infra. Eighty-one percent were women $(N=48)$.

The marital status was: married, $30 \%$; separated, $30 \%$; never married, $19 \%$; divorced, $14 \%$; widowed, $7 \%(\mathrm{~N}=47)$.

Two-thirds of the families had children $(\mathrm{N}=47)$. They averaged 2.3 children per family.

For the complaints of the tenants about conditions see Table 3 infra. Thirty percent of the tenants had single complaints and seventy percent had multiple complaints $(\mathrm{N}=44)$. Forty-three percent of the tenants lived in buildings that appeared from the outside to be either deteriorated or dilapidated $(\mathrm{N}=48)$.

For the nature of each tenants' case see Table 1. Seventy-one percent of the tenants moved in settlement of the dispute or soon after $(\mathrm{N}=48)$. 
supplement the information available in the legal services and court files. ${ }^{20}$ Information on the landlords was obtained from the county tax assessor's records and information on the condition of the property was obtained from the code enforcement agencies. Additional information about housing conditions in the study area was obtained by surveying the exterior of all property involved in unlawful detainer actions or tenant complaints. Finally, interviews were conducted with the legal services attorneys.

In all cases except the imterviews, $100 \%$ samples were obtained from the available data. In a few instances information was missing from files or there were misplaced files. These instances are indicated in the body of the Article or footnotes. Because of the small number of warranty tenants and landlords, the anticipated difficulty of obtaining interviews and the exploratory nature of the study, statistically random samples were not used in making interview selections.

\section{B. The Study Area}

The study area encompasses approximately fifteen square miles and a population of $95,000.21$ It is one of the oldest areas in the region, settled before the turn of the century. Like other areas in southern California, it grew in spurts and its population more than doubled from 1940 to the present. While the quality of life in the study area varies, the area as a whole has been rated by a public agency as having among the poorest living conditions in the region. Welfare department figures for October 1975 indicated that approximately 4,000 of the more than 25,000 families in the area were receiving Aid to Families with Dependent Children (AFDC).

20. Twenty-eight of the tenants were located. Twenty-five agreed to be interviewed. One interview was broken off. The tenants interviewed had approximately the same age, sex, and income demographics as the entire group of 48 tenants. They were, however, more often married (married 40\%; separated 30\%) and more often Anglo (Anglo 52\%; Latino 32\%). The primary differences from the total group were in the nature of their cases: unlawful detainers, 20\%; eviction notices, $20 \%$; nonevictions, $60 \%$. Thirty-six percent lived in buildings that appeared deteriorated and dilapidated. Forty-four percent had single complaints and fifty-six percent had multiple complaints. Fifty-two percent moved in settlement of the dispute or soon after. The interviews were designed to be exploratory. A questionnaire was constructed with fifty-four primarily open-ended questions and a narrative of the tenant's view of the process of the warranty dispute was taken. After five interviews the questions were reviewed. Some question areas were expanded. Two of the first five interviewees were reinterviewed. The interviews took about one hour.

Attempts to interview the landlords were largely unsuccessful. The landlords were contacted by letter from the university and, when possible, by phone. Only three consented to be interviewed and one of these broke several appointments. The absence of these interviews means that the subtleties of the warranty's impact on landlords cannot be reported. Substantial information on landlords is available in public records, and neutral information on the validity of tenant complaints and the condition of the subject property is available from code enforcement agencies; this information is reported in the Article.

21. The figures cited in this section are taken from the 1970 United States Census and from city projections based on 1970 census data from October 1975 unless otherwise indicated. The exact documents cannot be identified because of the need to protect the confidentiality of the clients. 
These families were composed of over 13,000 individuals. In addition to those receiving AFDC, more than 5,000 individuals received Supplemental Security Income.

Fifty-six percent of the more than 35,000 housing units in the area are rental units. The vacancy rate in these units is about $4 \frac{1}{2} \%$. Thirty-two percent of the housing in the area was constructed before 1940, and another $22 \%$ was constructed in the 1940 's, including war-time public housing. Some 3,800 units have been rated unsound by a city agency, but the standard used includes items irrelevant to the warranty standard, such as overcrowding. The average rent for those below the poverty line in 1970 was $\$ 92.11$ per month, with nearly $40 \%$ of the tenants in the study area paying more than $25 \%$ of their income in rent. Estimates for 1975 are not available, but the study suggested that rents have been rapidly rising in recent years. ${ }^{22}$

The population of the study area is $57 \%$ white, $35 \%$ Spanish surnamed, 5\% black and 3\% others, including Native Americans and Samoans. If the census tracts in the study area with more than $\$ 10,000$ per year average income are excluded, the percentages of whites and Spanish surnamed are virtually even, and the percentage of blacks rises to $6 \%$. As in other heavily Latino areas of southern California, Spanish speaking individuals may be substantially undercounted, because of the presence of foreign nationals without documents.

\section{Legal Services}

The legal services program had maintained an office in the study area for ten years prior to the commencement of this study. During the study period the staff was composed of five attorneys, three paralegals, three secretaries and numerous volunteers. The intake of the office for this period was 4,193 cases, a $24 \%$ increase over the previous year. Three hundred and eighty-one of the cases involved landlord-tenant disputes. Of these cases, 245 represented tenants eligible for legal services assistance living within the study area. In this group there were forty-eight warranty clients. These tenants lived in thirty-nine buildings owned by thirty-four landlords. The legal problems confronting the eligible tenants are set forth in Table 1.

\section{The Court}

Three judges sit for the branch of the municipal court that serves the study area. One of these judges hears most of the landlord-tenant cases. Six hundred and seven civil cases were filed in this branch of the court during the study period. Of these, 206 were unlawful detainer actions involving property within the study area. Only eleven answering pleadings were filed, $(\mathrm{N}=41)$.

22. The average rent paid by the legal services clients during the study year was $\$ 146.41$ 
Table 1

\begin{tabular}{|c|c|c|c|c|c|c|c|c|c|c|c|}
\hline & \multicolumn{8}{|c|}{$\begin{array}{l}\text { Analyses of Legal Service Intakes } \\
\text { oblem with Conditions No Problem with Conditions }\end{array}$} & \multirow{2}{*}{\multicolumn{3}{|c|}{ Total }} \\
\hline & $\frac{\text { Prot }}{\text { Cases }}$ & $\frac{\text { em with }}{\text { Clients }^{23}}$ & $\frac{\text { Cond }}{\%}$ & $\frac{t i o n s}{\%}$ & $\frac{\text { No Pro }}{\text { Cases }}$ & $\frac{\text { blem wit }}{\text { Clients }}$ & $\frac{\mathrm{h} \mathrm{Co}}{\%}$ & $\frac{\text { ditions }}{\%}$ & & & $\%$ \\
\hline $\begin{array}{l}\text { Unlawful } \\
\text { Detainers } \\
\text { Eviction }\end{array}$ & 14 & (13) & 24 & (22) & 45 & (45) & 76 & (78) & $59^{24}$ & (58) & 100 \\
\hline Notices & 18 & (14) & 18 & (16) & 80 & (73) & 82 & (84) & $98^{25}$ & (87) & 100 \\
\hline & $\frac{23}{55}$ & $\frac{(21)}{(48)}$ & 26 & $\frac{(25)}{(21)}$ & $\frac{65}{190}$ & $\frac{(63)}{(181)}$ & $\frac{74}{78}$ & (75) & $\frac{88}{245}$ & $\frac{(84)}{(2029)}$ & 100 \\
\hline
\end{tabular}

ten by legal services attorneys and one in propria persona. None of the cases resulted in a trial. Unlawful detainer actions are not accepted in small claims court in this jurisdiction. Law and motion matters and jury trials are transferred to the main branch of the court.

\section{II}

\section{GREEN AND HOUSING POLICY}

The central issue behind the warranty of habitability debate is the likely impact of the warranty on the housing stock and the housing market, particularly that portion of the housing stock and market occupied by lowincome tenants. The opponents of Green point to eastern slums with deteriorated tenements, fleeing investors and massive abandonment, arguing that anything, including the warranty, that places additional pressures on the landlords can only drive California toward the eastern situation. Proponents argue instead that Green will slow that decline. The proponents argue that the nature of the housing market in low-income areas necessitates legal intervention, and that there is money which can be diverted to repair of the property. ${ }^{26}$ All parties seem to assume that Green addresses a pervasive problem of California's low-income housing stock. The findings of this study indicate a less pervasive problem than anticipated, little or no impact of Green on an active housing market and a positive impact on the condition of housing.

\section{A. The Size and Condition of the Housing}

Examination of the housing occupied by the warranty tenants and the defendants in unlawful detainer actions, and a review of the complaints of the warranty tenants suggest that the California low-income housing situation differs markedly from the eastern image. Much of the California housing stock, including that in the study area, is dominated by structures smaller and in better condition than the infamous abandoned New York

23. "Cases" are distinguished from "clients" in that some clients had more than one intake sheet.

24. Nine involved forcible eviction by the landlord.

25. Twenty-one involved forcible eviction by the landlord.

26. See P. Weitzman, supra note 10 , passim. 
walk-up tenement. About half of the warranty clients and unlawful detainer defendants lived in buildings containing four units or fewer, and few lived in buildings of twenty urits or more. ${ }^{27}$ Table 2 summarizes the number of units per structure in buildings involved in unlawful detainer and warranty actions.

Table 2

Number of Living Units per Structure Percentage Distribution

\begin{tabular}{|c|c|c|c|c|}
\hline \multirow[b]{2}{*}{ Units Per Structure } & \multicolumn{2}{|c|}{ Unlawful Detainers } & \multicolumn{2}{|c|}{$\begin{array}{l}\text { Legal Services } \\
\text { Warranty Cases }\end{array}$} \\
\hline & By Case & By Structure & By Case & By Structure \\
\hline 1 & $15.0 \%$ & $20.0 \%$ & $17.0 \%$ & $20.5 \%$ \\
\hline 2 & 12.0 & 14.5 & 10.0 & 13.0 \\
\hline 3 & 1.0 & 2.0 & 0.0 & 0.0 \\
\hline 4 & 25.0 & 25.0 & 21.0 & 26.0 \\
\hline $5-8$ & 20.0 & 21.5 & 25.0 & 28.0 \\
\hline $10-16$ & 14.0 & 8.5 & 21.0 & 5.0 \\
\hline $20+$ & 12.5 & 8.0 & 6.0 & 7.5 \\
\hline Mobile & 0.5 & 0.5 & 0.0 & 0.0 \\
\hline & $\begin{array}{l}100.0 \\
N=206\end{array}$ & $\begin{array}{c}100.0 \\
N=158^{28}\end{array}$ & $\begin{array}{l}100.0 \\
N=48\end{array}$ & $\begin{array}{l}100.0 \\
N=39^{28}\end{array}$ \\
\hline
\end{tabular}

Although the study area is one of the oldest in southern California, an evaluation of the exteriors of the properties where unlawful detainer actions took place suggested that most tenants lived in basically sound housing. Twenty-three percent (48) of the tenants evicted lived in apparently deteriorating or dilapidated structures. ${ }^{29}$ Of this $23 \%$, the majority (27 of 48) fell in the deteriorating category. A similar evaluation of the housing occupied by the warranty tenants found that $39 \%$ (18) of the tenants lived in properties that appeared to be deteriorating and only $4 \%$ (2) lived in dilapidated structures. ${ }^{30}$ The suggestion that most complaining tenants in-

27. In the Western Region, $19.2 \%$ of families live in structures with 20 or more units. In the Northeastern Region, $27 \%$ of families live in structures with 20 or more units. BUREAU OF Census, U.S. Dep'T. of Commerce, ANnual Housing Survey: 1975, Financial Characteristics OF THE HOUSINg INVENTORY (PART C), SERIEs H-150-75 C, 1977. The difference between the East and West is accentuated in construction figures for the 1960-70 period. In New York, $\mathbf{7 4 . 4 \%}$ of construction was of structures of 20 or more units. In Los Angeles, only $36.1 \%$ of construction was of structures of $\mathbf{2 0}$ or more units. For the construction of units that rented for $\$ 99$ or less, the difference is even greater: $50 \%$ of the structures in New York had 20 or more units and $15 \%$ of the structures in Los Angeles had 20 or more units. BUREAU OF CENSUS, U.S. DEP'T. OF COMMERCE, 1970 CENSUS OF Housing, CoMponents of INVENTORY Change, SERIES $\mathrm{HC}(4), 1973$.

28. The numbers have been reduced to indicate multiple cases in individual structures.

29. The standard employed in the exterior evaluation is set forth in Form BD-164(2) 040274, entitled "Condition of Housing Units" available from the California Department of Finance. "Deteriorated" means ordinary maintenance could not solve the problem but the structure provides adequate shelter. "Dilapidated" means one or more critical defects or a combination of intermediate defects.

30. Only two appeared dilapidated. In addition, one structure was demolished and another was burnt. Only 2 of the 12 properties with single problems appeared deficient, and only 9 of the 23 properties with multiple problems appeared deficient. This seems to indicate 
habited readily repairable property is confirmed by an examination of the tenants' specific complaints.

Thirty percent (13) of those with complaints identified only a single item that needed repair. While there were a great variety of complaints, the most common subject of complaint was plumbing. Sixty percent of the tenants had plumbing problems, a complaint approximately twice as frequent as any other. While plumbing problems undermine habitability, they do not necessarily indicate a structural defect that is beyond repair. Indeed, most of the plumbing problems reported in the study ultimately were corrected by landlords. ${ }^{31}$ The nature of tenants' complaints is summarized in Table 3.

Table 3

\begin{tabular}{|c|c|c|}
\hline \multicolumn{3}{|c|}{ Complaints About Conditions } \\
\hline Complaint & No. & Percent of Cases \\
\hline Plumbing & 26 & 60 \\
\hline Windows & 15 & 34 \\
\hline Floors & 14 & 32 \\
\hline Screens & 13 & 30 \\
\hline Bugs & 11 & 26 \\
\hline Ceilings & 10 & 23 \\
\hline Hot water & 9 & 20 \\
\hline Appliances & 8 & 18 \\
\hline Heat & 6 & 14 \\
\hline Doors & 6 & 14 \\
\hline Electrical & 6 & 14 \\
\hline Walls & 6 & 14 \\
\hline Rodents & 5 & 11 \\
\hline Gas leaks & 3 & 7 \\
\hline Trash & 3 & 7 \\
\hline Mildew & 2 & 5 \\
\hline Carpet & 2 & 5 \\
\hline Venting & 2 & 5 \\
\hline Cleaning & 1 & 2 \\
\hline$N=44^{32}$ & & \\
\hline
\end{tabular}

The length of the tenant's tenure before a problem emerged also provided evidence of the condition of the housing. ${ }^{33}$ Only a quarter of the tenants interviewed had problems in the first 6 months of their tenancy. The median stay before problems began was 8 months and the mean was 14.5 months. Although this does not establish that the housing was in perfect condition, it shows the more gradual trend of worsening conditions as-

warranty problems cannot always be seen from the outside. It does not, however, negate the implication that the housing is in decline rather than in decay.

31. See notes 50-55 infra and accompanying text.

32. Four legal services files contained only general reference to problems with conditions.

33. The tenancy period before a warranty problem emerged for some of the clients was: under six months, 7; six months to one year, 9; one year to two years, 5; over two years, 4 $(\mathrm{N}=25)$. 
sociated with declining property. With slum-like property on the other hand, one would expect complaints commencing shortly after taking occupancy.

\section{B. The Housing Market and Ownership Pattern}

The opponents of the warranty argue that the low-income portion of the housing market has lost its vitality and is therefore vulnerable to the pressure generated by the warranty. This loss in vitality is usually indicated by the transfer of ownership to what is thought of as the final owner before abandonment, the local, ethnic, small-scale investor. ${ }^{34}$ Stereotypically, this owner has little capital and has been left holding the bag after a piece of property has been exploited by the larger investor who has moved on to more lucrative investment opportunities. This landlord buys a piece of property in need of repair, only to find that financing is difficult to obtain. If he chooses to resell the property, he has trouble finding a new buyer.

Analysis of ownership patterns in the study area shows a different picture. The study area was being impacted along with other areas of southern California by the extraordinary pressures on the housing market in this period. ${ }^{35} \mathrm{~A}$ search of the tax assessor's records indicated a high turnover rate in the properties occupied by warranty clients with a high percentage of transfers to other than local investors.

Sixty-four percent (25) of the subject properties were purchased in the 1970 's. ${ }^{36}$ Nearly half of these purchases (12) were made by investors living outside the study area. This is in contrast with the finding that eight of nine investors who have held their property more than ten years live in the study area. ${ }^{37}$ The mean size of the study area property owned and the number of parcels owned of record in the study area was larger for those who lived outside the study area than for those who lived in the study area. ${ }^{38}$ Furthermore, the more recent purchasers who lived in the study area also owned larger structures and more parcels than the older owners. ${ }^{39}$ The relation between the number of buildings owned by landlords and the number of units per building is set forth in Table 4. In general, the larger the structure, the more parcels the landlord owned.

34. G. STERNLIEB \& R. BURChELL, RESIDENTIAL ABANDONMENT (1973).

35. See note 21 supra and accompanying text; notes 36 and 59 infra and accompanying text.

36. Compare G. Sternlieb, The Tenement Landlord 100 (1969) (33.6\% purchased in the previous six years); G. STERNLIEB \& R. BURCHELl, supra note 34, at 100 (33.5\% purchased in period 1965-1971). Of those properties purchased in the past 10 years, 14 had been sold once, 7 were sold twice, 4 were sold three times, 4 were sold four times and 1 was sold seven times. The mean number of sales of such properties was 2.1 times. Nine properties purchased over 10 years ago had remained with that owner for 10 years.

37. Overall, $22(65 \%)$ lived in the study area and $12(35 \%)$ lived outside the study area. One of the 12 lived outside the county and another outside the state.

38. Their ratio was 10 units per structure compared to 3.75 per structure for those owned by local landlords.

39. Four units and 3.9 parcels for purchasers since 1970 to 3.6 units and 2.9 parcels for purchasers before 1970 . 
Table 4

Relation of Units in Buildings to Holdings of Landlord

\begin{tabular}{|c|c|c|c|c|c|c|c|c|c|c|c|}
\hline \multicolumn{12}{|c|}{ Units per Building } \\
\hline & 1 & 2 & 4 & 5 & 6 & 7 & 8 & 10 & 15 & $20+$ & Total \\
\hline 1 & 2 & 2 & & & & & & & & & 4 \\
\hline 2 & 2 & & 4 & 1 & & & & & & & 7 \\
\hline 3 & 2 & & 2 & $1^{40}$ & 3 & 1 & & & & & 9 \\
\hline 4 & 2 & $1^{\circ}$ & 1 & & & & & 1 & & & 5 \\
\hline 5 & & & 1 & & & & & & & & 1 \\
\hline 7 & & & & & 1 & 1 & & & & & 2 \\
\hline 8 & & 1 & & & & & & & & & 1 \\
\hline 10 & & & 1 & & & & 3 & & & & $4^{41}$ \\
\hline $35 t$ & & 1 & 1 & & & & & & $1^{42}$ & 3 & $6^{43}$ \\
\hline Total & 8 & 5 & 10 & 2 & 4 & 2 & 3 & 1 & 1 & 3 & $3 9 \longdiv { 3 9 }$ \\
\hline
\end{tabular}

The check of the tax assessor's records also indicated that in the case of warranty clients there was a total absence of resident landlords, landlords who live on the property they are renting out. This is significant since such landlords have been characterized as "prinie generators of good maintenance." 44 The absence of these landlords in this study would seem to confirm this characterization. It is also inportant because the application of the warranty is not triggered unless a landlord fails to respond to a request for repair. The findings indicate that most landlords, even in low-income areas, maintain their property and that warranty landlords are an exception.

Half of the warranty clients had out-of-area landlords, but this was due to the presence of two individuals who, between them, were landlords of nearly $30 \%$ of the warranty tenants. ${ }^{45}$ One was a large speculator who clainied to own sixty-four pieces of property in southern California with many of his holdings under land sale contracts. ${ }^{46}$ The other was a developer who had accumulated thirty-five pieces of property on the edge of the study area for clearance and the construction of a condominium development. ${ }^{47}$ Only $19 \%$ (9) of the warranty clients had local landlords with smaller holdings who had owned their property for longer than ten years. The remaining warranty clients were tenants of landlords who lived in the area and had purchased their property within the last ten years.

40. Two warranty clients lived in the structure.

41. One landlord owned two eight-unit structures.

42. Nine warranty clients lived in the structure.

43. One landlord owned a 4- and a 15-unit structure; another owned one structure with 2 units and three with more than 20 units.

44. G. Sternlieb, The Tenement Landlord xiii (1966).

45. The speculator was the landlord of ten warranty clients including nine tenants who joined together in a rent strike. The developer was the landlord of four warranty clients, each of whom lived in a different piece of property.

46. The tax assessor's record indicated that this landlord owned 35 pieces of property. Ownership of numerous holdings under land sale contracts, which are not recorded, is typical of speculators.

47. The developer was the only landlord who lived out of state. He owned all the buildings occupied by warranty clients that contained 20 or more units. 


\section{Green's Impact on the Housing Market and Housing Stock}

Having found a less pervasive warranty problem than anticipated and a more vital housing market than that described by the opponents of Green, it would seem reasonable to conclude that the use of the warranty in the study area had little immediate impact on the housing market. The issue of the warranty's general impact on the housing market presents very complex issues well beyond the scope of this case study. Many factors enter into the marginal choices made by mvestors. Unfortunately, the information that might have been gathered to shed light on this decision process was lost when most of the landlords declined the invitation to be intervewed. ${ }^{48}$

Aside from the question of the inpact of Green on the housing market, its proponents and opponents make specific claims about the impact of the warranty. Green's proponents claim that the warranty will lead to repair of the housing stock and that repairs will be made without substantial increases in rents. They argue that Green will prevent the accumulated neglect that makes it impossible to repair a piece of property economically. By consistently placing pressure on the landlord to divert a portion of the rental flow to maintenance and repair of the property, the warranty stalls abandonment and keeps housing units on the market.

Green's opponents predict that the warranty will deplete the housing stock by making repairs impossible. If the tenant withholds the rent, there will be no funds to make the repairs or, worse, to pay the mortgage or property taxes. They argue that any interruption in the rental flow places the landlord in an untenable position. With limited funds available and near unlimited demands on that money, the landlord is apt to choose the easiest way out and abandon the property.

Green's opponents argue that the warranty is a sword aimed as much at the tenant as at the landlord. If the landlord finds a way to make repairs, rents will have to be raised to recoup the cost of making those repairs. If the choice is between abandonment and raising rent, the low-income tenant, who is supposed to be the beneficiary of the warranty, loses either way. This problem is exacerbated because tenants can abuse the law. Knowing that the landlord is vulnerable to even a short term interruption in the rents, tenants can claim a violation of the warranty, legitimately or not, and insist on protracted litigation to resolve the issue. This may force the landlord to yield to tenants' demands that are unrelated to the warranty and create another incentive for abandonment.

The findings of this study tend to support the position put forward by the supporters of the Green doctrine. This support is tentative, however, as the scenario found in the study area did not match that anticipated by the proponents. Most of the property occupied by warranty clients was repaired, but it is difficult to determine the extent to which Green was responsible.

48. See note 20 supra. 
The rents of those who remained in the property after repairs were made were not raised substantially, but a majority of the tenants moved as part of the resolution of the warranty dispute. Finally, little abuse of the law was found.

\section{Property Was Repaired}

At least $80 \%$ (39) of the property occupied by the warranty clients was repaired after tenants lodged their complaints. ${ }^{49}$ The extent to which the warranty was a factor is unclear. Tenant pressure, lawyer pressure and code enforcement, as well as the threat or use of the warranty or the repair and deduct statutes ${ }^{50}$ all played a part. The most definite statement that can be made is that the existence of warranty increased the aggressiveness of the lawyers. The ambiguity results not only because so many factors were involved, but also because none of the warranty cases went to trial.

The involvement of the code enforcement agencies appeared to be a particularly important part of the repair process. Tenants' use of code enforcenient is analyzed in Table 5 . To prepare for possible warranty litigation, the legal services attorneys had developed a referral form to aid their clients in reporting problems to the code enforcement agencies. All the clients, other than those who had already filed a complaint with the code enforcement agency or whose case could be quickly resolved by negotiations or the use of the repair-and-deduct statutes, were asked to fill out one of

Table 5

\section{Tenants' Use of Code Enforcement}

\begin{tabular}{lccc}
\multicolumn{1}{c}{ Tenants' Action } & $\begin{array}{c}\text { Number of } \\
\text { Tenants }\end{array}$ & $\begin{array}{c}\text { Landlords } \\
\text { Cited }\end{array}$ & $\begin{array}{c}\text { Tenants } \\
\text { Cited }\end{array}$ \\
\hline $\begin{array}{l}\text { Report violations before coming } \\
\text { to legal services }\end{array}$ & 8 & 8 & - \\
$\begin{array}{l}\text { Reported violations after referral } \\
\text { by legal services }\end{array}$ & 26 & 24 & 2 \\
$\quad$ Repaired before inspection) & $(1)$ & $(-)$ & $(-)$ \\
$\quad$ File could not be located) & $(1)$ & $(-)$ & - \\
$\begin{array}{l}\text { Declined to report } \\
\text { Repairs obtained by negotiations } \\
\text { before report }\end{array}$ & $4^{51}$ & - & - \\
$\begin{array}{l}\text { Repairs sought by threat or use of } \\
\text { repair and deduct statutes }\end{array}$ & 6 & - & - \\
& $\frac{4}{48}$ & - & - \\
\hline
\end{tabular}

49. This was determined from code enforcement and legal services records and from the interviewed tenants. If code enforcement was not involved and the tenant moved, it was not determined whether repairs took place.

50. Cal. Civ. Code $\$ \S 1941-1942.1$ (West Supp. 1977).

51. Two decided to move and not press the issue; one was forcibly evicted and did not follow through; one feared retaliation. 
these forms. Code enforcement agencies cited the landlord in thirty-two cases. In twenty-three of these cases the legal services attorneys had sent the tenant to a code enforcement agency. In all but one instance the violations found were cleared by the landlord. This is an extraordinary result in light of the troubled history of code enforcement in this country. ${ }^{52}$

The local code enforcement officials felt that Green might have been a factor in their success, but they could not be sure. They observed that since they had begun to inform landlords of the substantial potential penalties for interrupting utilities as a means of eviction, the number of utility interruption cases had been steadily declining. ${ }^{53}$ They thought that the potential loss in rent from a violation of the warranty might have a similar effect. The major reason for their uncertainty is that prior to being interviewed, the code enforcement officials had never heard of Green or the warrant of habitability. ${ }^{54}$ They remained uninformed even though legal services attorneys regularly referred these cases to the code enforcement offices. Upon learning of Green, an inspector replied, "Boy, that will sure open up a can of worms." This was nearly three years after the can had been opened. The head of one of the agencies explained that they kept up with the codes but not the cases.

Two specific cases lend some credibility to the anti-Green position. In one case the coinbination of the warranty and code enforcement ended in partial abandonment of the property. The landlord brought an unlawful detainer action against one of his tenants. The tenant brought the summons and complaint to the legal services office and was referred to a code enforcement agency. The landlord was cited for having several units with housing code violations. He responded to a repair order by closing the offending units. ${ }^{55}$

In the other case, the large speculator described earlier responded to a rent strike by nine of his tenants and a code enforcement citation by claiming he could not afford to repair the property if the tenants withheld their rent. The legal services attorney and the tenants decided to release the rent money to the landlord on the condition that it be spent to repair the property. The repairs were made. With this result, the latter case could also be cited for the proponents' position. Arguably if it were not for the law and the strike, these funds would have gone to expand the landlord's investment program rather than to the repair of the property.

52. See 3 THE URB. LAW. 525 (1971) (special issue reporting on proceedings of the A.B.A. National Institute on Housing Code Enforcement).

53. CAL. CIV. CODE $\$ 789.3$ (West Supp. 1977) provides for up to $\$ 100$ per day in damages if the landlord cuts off the tenant's utilities with the intent to evict.

54. This would indicate that it was unlikely that code enforcement was broadened as a result of Green, as argued by the proponents.

55. Although moving from a deficient unit to a more functional one, the tenant lived rent free until he left seven months later. In this unusual case, the landlord offered the tenant the job of manager of the apartment house after the dispute began. The tenant rejected the offer. 


\section{E. The Impact on Rent}

The proponents of the warranty have predicted that landlords would make repairs without imposing increases in rent. ${ }^{56}$ This study supports that position if it is limited to the approximately one-third of the cases where the tenants did not move as part of the settlement of the warranty dispute..$^{57}$ Although several tenants who did not move were threatened with increases, only one case resulted in a rent raise that can be directly traced to the cost of repairs. ${ }^{58}$ In that case, a tenant, with the help of a legal services attorney, induced the landlord to install a new heater in the tenant's apartment. The landlord, claiming that the heater and its installation cost $\$ 300.00$, raised the rent from $\$ 95.00$ to $\$ 125.00$ per month in order to recapture his expenditure. After a discussion with the legal services attorney that included reference to the prohibition against retaliation, ${ }^{59}$ the landlord was persuaded to amortize the costs he incurred over a longer period and to reduce the rent increase to $\$ 5.00$ per month.

What happened in the other two-thirds of the cases is unknown. Even if data on these cases were available, it would be difficult to interpret in light of the inflationary and speculative housing market in the study area. ${ }^{60}$ The average rent paid by the warranty clients was $\$ 146.41$ per month as compared to the $\$ 92.11$ average for low-income people reported in the 1970 census, and rents in the area continue to rise. The difficulty in determining the impact of the warranty on rents is demonstrated in the following case. A tenant had been living in her apartment for a year, paying $\$ 145.00$ per month, when the property was sold. The new landlord immediately raised the rent $\$ 20.00$ to $\$ 165.00$ per month. A problem with the plumbing occurred which the landlord refused to repair. With the help of a legal

56. The opponents of Green argue that rents will only remain stable in the short run. See, e.g., Weitzman, supra note 10 , passim. Whether or not rents go up in the long run is beyond the scope of this study.

57. Determining who stayed and who moved as a result of the dispute was difficult. For example, only $13(27 \%)$ stayed for a substantial length of time. Seven (15\%) were not evicted but nevertheless moved after the rent strike against the speculator fell apart. The other two tenants involved in that rent strike left after being served with a summons and complaint for unlawful detainment. Only 15 moves were negotiated by legal services; 12 of these were in unlawful detainer actions.

58. Two additional tenants had their rent raised $\$ 10$ per month because of increases in taxes; another was clearly retaliated against when his rent was doubled immediately after he reported his problem to a code enforcement agency. The absence of further rent raises suggests that the warranty tenants who remain in possession had their rents stabilized against the inflationary pressures of the period.

59. The relation of Green and the warranty to the prohibition against retaliation is discussed in Moskovitz, supra note 7, at 1493-1501. See also Note, California Common Law Defense Against Landlord Retaliatory Conduct, 122 U.C.L.A. L. Rev. 1161 (1975) which argues for unrestricted common law protection for use of the warranty, instead of the statutory protection of 60 days provided in CAL. Civ. CODE $\S 1942.5$ (West Supp. 1977).

60. An attempt to do such analysis on a large scale was made by W. Hirsch, J. Hirsch and S. Margolis in Regression Analysis of Effects of Habitability Laws Upon Rent, 63 CALIF. L. REV. 1098 (1975). See also Rittel \& Webber, Dilemmas in a General Theory of Planning, 4 POL'y SCI. 155 (1973). 
services attorney, the tenant got the landlord to make the requested repairs. A few months later, however, this landlord sold the property, and the third landlord raised the rent another $\$ 20.00$ per month. In such situations it seems more likely that the warranty captured part of the speculative gain rather than raised rents.

\section{F. Little Evidence of Abuse}

Green appears not to have been abused by tenants and their attorneys to harass landlords. The lawyers, pressed by the size of the intake in their office, had no inclination to loosely employ the Green defense. They generally limited their efforts to making sure that defendants in unlawful detainer cases received the legal protection to which they were entitled. In one case, the attorneys felt that the client had abused the law and was a "professional" troublesome tenant. When the tenant returned with a second case, the attorneys denied her the services of the office. The major evidence for the finding of little abuse is the fact that in almost every instance in which a report was filed, inspection by the code enforcement official resulted in the issuance of an "order of repair" to the landlord.

The fact that the code enforcement agencies issued an order of repair does not mean that all of a tenant's complaints were confirmed. If the orders of repair are compared with the legal service's referral forms, the situation assumes greater complexity. Table 6 shows the ratio of tenants' complaints

Table 6

Comparison of Tenants' Complaints and Code Enforccnient Citations

\begin{tabular}{lccc|ccc} 
& Complaints & Confirmed & $\begin{array}{c}\text { Not } \\
\text { Confirmed }\end{array}$ & Citations & Complaints & $\begin{array}{c}\text { Not } \\
\text { Complained }\end{array}$ \\
\hline Plumbing & 18 & 10 & 8 & 11 & 10 & 1 \\
Windows & 11 & 7 & 4 & 10 & 7 & 3 \\
Floors & 10 & 7 & 3 & 9 & 7 & 2 \\
Screens & 9 & 6 & 3 & 10 & 6 & 4 \\
Appliances & 6 & 4 & 2 & 8 & 3 & 5 \\
Walls & 6 & 3 & 3 & 6 & 3 & 3 \\
Doors & 6 & 1 & 5 & 2 & 1 & 1 \\
Bugs & 5 & 4 & 1 & 5 & 4 & 1 \\
Heaters & 5 & 2 & 3 & 3 & 2 & 1 \\
Electrical & 4 & 2 & 2 & 4 & 2 & 2 \\
Hot water & 4 & 2 & 2 & 3 & 2 & 1 \\
Ceilings & 3 & 2 & 1 & 3 & 2 & 1 \\
Carpets & 2 & 0 & 2 & 3 & 0 & 3 \\
Rodents & 2 & 1 & 1 & 1 & 1 & 0 \\
Trash & 0 & 0 & 0 & 6 & 0 & 6 \\
Furniture & 0 & $\underline{0}$ & $\frac{0}{40}$ & $\frac{2}{85}$ & $\underline{0}$ & $\frac{2}{30}$ \\
Total & 91 & 51 & & & & 36 \\
N=22 & & & & & & \\
\hline
\end{tabular}

61. There were no forms in seven legal services files, in four cases the existence of citations was confirmed on the phone and not included in this analysis, and in one case the code enforcement agency could not find its file. 
to agency citations. Although the numbers of complaints and citations are nearly identical, $46 \%$ of the complaints were not confirmed and $42 \%$ of the citations were for items different from those on the tenant's complaint form. The reason for this finding is not immediately apparent. The time which passed between the complaint and the code enforcement inspection may be one explanation. For example, there were cases in which plumbing had been repaired before the inspection took place. In other cases, the differences between complaints and citations may have been an expression of the different priorities of tenants and code enforcement inspectors.

Even if orders of repair were issued, one might question whether the violations were severe enough to meet the "materially affect health and safety" standard of Green. ${ }^{62}$ While this is difficult to determine from the evidence available, in all but two of the cases analysed above, the item cited seemed to concern serious matters. In the remaining two cases (which may also have been serious) the citations were limited to problems with trash, carpeting, furniture and screens. Of the cases not included in the analysis, all but one would appear to involve a serious violation. ${ }^{63}$

Aside from the attitude of the legal services attorneys, the character of the clients contributed to the absence of abuse. First, the majority of the tenants displayed an obvious good faith in their desire to obtain repairs. Seventy percent (34) of the tenants either paid their rent and then independently came to legal services to seek help in obtaining repairs or withheld their rent expressly for the purpose of obtaining repairs. ${ }^{64}$ Second, although

Table 7

\section{Source of Income of Warranty Clients}

\begin{tabular}{lcc} 
Source & All & $\begin{array}{c}\text { Those } \\
\text { Interviewed }\end{array}$ \\
\hline AFDC & $23^{65}$ & $12^{66}$ \\
AFDC-U & 3 & 1 \\
Social Security & 7 & $3^{67}$ \\
SSI & 3 & $2^{67}$ \\
Employment & $10^{65}$ & $6^{66}$ \\
Unemployment & 1 & 1 \\
Student Benefits & 1 & 1 \\
\hline & $\mathrm{N}=42^{68}$ & $\mathrm{~N}=24$
\end{tabular}

62. For a discussion of possible interpretations of the phrase "materially affect health and safety" see Moskovitz, supra note 7, at 1458-64.

63. The serious cases involved one or more of the following: plumbing, bugs, heaters, walls, ceilings or floors. In four cases, the particular nature of the complaints could not be determined from the available information.

64. Seventeen paid their rent and seventeen withheld to force repairs. Only thirteen warranty clients had not paid their rent for some other reason. Ten of these tenants did not have the money and three were withholding rent to accumulate enough to move. Two-thirds of those who had been served with a summons and complaint in unlawful detainer were among the thirteen. There was one case in addition that was ambiguous on this point.

65. Three people were employed part-time and received AFDC.

66. One person was employed part-time and received AFDC.

67. One person received both social security and supplementary security income.

68. Six legal services files were incomplete in this regard. 
the warranty tenants were representative of low-income communities, as indicated in Table 7, they generally did not have an extensive history of landlord-tenant problems.

As is typical of low income communities, most of the tenants interviewed had lived and moved within the study area for a long period of time. ${ }^{69}$ Table 8 sets forth the location and average length of time spent by the tenants in their prior residences. Forty-three percent of these tenants had left the apartment they occupied before renting the subject property for what are termed "involuntary reasons." 70 The reasons for the tenants' moves from their prior residences are listed in Table 9. Contrary to common wisdom, only $40 \%$ (10) had experienced problems with conditions or landlords in the three apartments in which they previously had lived. Only $12 \%$ (3) had had more than one bad experience. In fact, $80 \%$ (20) of those interviewed stated that the subject property was the worst in which they had lived. Before this current experience, only $25 \%$ (6) had ever been evicted, half of these (3) after withholding rent to obtain repairs. One tenant had successfully employed the repair-and-deduct remedy. It may be that this study has sainpled a population experiencing downward mobility in housing quality due to the reduced housing choice that accompanies inflating rents as well as the existence of a decliming housing stock. ${ }^{71}$

Table 8

Length of Stay and Location of Prior Residences

\begin{tabular}{lccc} 
& Prior & Second Prior & Third Prior \\
\hline $\begin{array}{l}\text { Average Stay } \\
\quad \text { in Years }\end{array}$ & 1.5 & 2 & - \\
Location: & & & \\
In study area & 17 & 15 & 14 \\
In general area & 3 & 5 & 3 \\
In region & 3 & 2 & 4 \\
Out of state & 2 & 3 & 4 \\
$\mathrm{~N}=25$ & & &
\end{tabular}

III

GREEN AND OUR SYSTEM OF JUSTICE

A great deal of lawyers' attention is focused on the process of law

69. See N. Foote, J. Abu-Lughod, M. Foley \& L. WinNick, Housing Choices ANd HOUSING CONSTRAINTS 121-30 (1960).

70. See, e.g., P. Rossi, Why Families Move 135 (1955).

71. The common theory is that the housing problem will be solved by the market with some governmental inducements. As new housing is built the older housing occupied by those better off "trickles down" to the poor. The findings here indicate the contrary may be true at this time. In effect, the tenants were "trickling down"' as the housing market tightened. For a discussion of the issue see Lowry, Filtering and Housing Standards: A Conceptual Analysls, 36 LAND ECON. 362 (1970). 
Table 9

\begin{tabular}{|c|c|}
\hline Reason & $\begin{array}{l}\text { Number of } \\
\text { Tenants }\end{array}$ \\
\hline Move from parents' home & 5 \\
\hline Move because of work & 4 \\
\hline Move to obtain more space & 3 \\
\hline \multicolumn{2}{|l|}{ Involuntary: } \\
\hline Evicted & 2 \\
\hline Rent raised & 2 \\
\hline Property sold & 2 \\
\hline Property torn down & 1 \\
\hline Property remodelled & 1 \\
\hline Conditions & 1 \\
\hline Divorce & 1 \\
\hline
\end{tabular}

reform. Far less attention is given to what happens once a law is reformed. ${ }^{73}$ The previous sections of this Article explored the impact of Green on housing. In the following sections the role of the justice system in the implementation of Green will be examined. ${ }^{74}$ This study found that the court docket, employed as an indicator in the San Francisco study, was an inadequate indicator of Green activity in the study area, because a substantial portion of warranty use did not involve the courts. In addition, it was found that although the San Francisco study correctly concluded that Green is little known, the rule of Green is in fact consistent with the sense of justice upon which tenants act. It was also found that, beyond the problem of knowledge of the law, problems with the courts, the lawyers, the holding of the case, and the clients all interfere with Green's full application. Finally, it was found that while rent strikes occurred, the tenant unions predicted by Green's proponents did not materialize.

\section{A. The Level of Activity}

The findings of this study place some of the assumptions and conclusions of the San Francisco study in doubt. ${ }^{75}$ In the San Francisco study, only $15 \%$ of the tenants who were defendants in unlawful detainer cases made formal appearances. ${ }^{76}$ The rest of the cases were abandoned or default judgments were obtained against the tenants. In the study area examined in this Article, the percentage of appearances was even smaller. Tenants filed

72. Three people interyiewed did not answer the question.

73. For two examples of such investigations see W. MUIR, JR., PRAYER IN THE PUBLIC Schools (1967) and K. Dolbeare \& P. HaMmond, The School Prayer Decisions (1971).

74. The term "justice" is used to indicate more than the formalized legal system. The question of whether justice was done has importance beyond the question of the law's impact on housing. The landlord-tenant relationship is a central one in our society. A study conducted by the police department of Oakland, California found breakdowns in this relationship to be a major cause of violence in the city. Moody, Landlords and Tenants: Oakland's Landlord/Tenant Intervention Unit, 39 THE POLICE CHIEF 32 (1972).

75. See Green Hope, supra note 16, at 729.

76. Id. at $739-40(202 / 1,314)$. 
responsive pleadings in only 5\% (11) of the 206 cases. In San Francisco, $58 \%$ of the tenants made their appearances with the help of a legal services attorney and the remainder either appeared with private attorneys or in propria persona. ${ }^{77}$ In this study, all but one of the tenants who made appearances did so with the assistance of a legal services attorney. The remaining tenant appeared in propria persona. In San Francisco, legal services attorneys made most of the appearances raising the Green defense. ${ }^{78}$ In this study, legal services attorneys made all of the appearances raising the issue of the warranty. In total, Green was raised by appearance in $4 \%$ of the San Francisco actions, ${ }^{79}$ and in only $2.4 \%$ (5) of the actions in this study. Thus, judging from court records this study confirms the San Francisco finding of inactivity and ineffectiveness.

An examination of the legal services files tells a far different story. While only $5 \%$ of the tenants who were defendants in unlawful detainer actions in this study made formal appearances, $25 \%$ (52) of the tenants who were named in unlawful detainer actions went to the legal services office seeking counsel. ${ }^{80}$ In most instances, these cases were resolved without formal appearance. In effect, there was a five to one ratio of legal counseling to court appearances. It is possible that a similar ratio between counselmg and appearances existed in San Francisco, although it would be improper to project the study area ratio on the San Francisco findings.

Another important finding resulted from examining the files of all the unlawful detainer defendants (58) who came to the legal services office. ${ }^{81}$ Although it was office policy to ask all such clients about the condition of their housing to determine if they had a warranty claim, only $22 \%$ (13) of them reported problems with the condition of their apartment. ${ }^{82}$ If this percentage of problems holds among all evicted tenants, it would mean that there are far fewer potential Green defenses than any of the opinions identified in this article have assumed. ${ }^{83}$ Instead of stating Green appear-

77. Id. at $750(117 / 202)$.

78. Id. at $750-51(82 \%-46 / 56)$.

79. Id. at $744(56 / 1,314)$.

80. This figure is only slightly higher than the results of a nationwide survey of the use of lawyers in various types of matters, including eviction actions. In such actions, $23.3 \%$ of the respondents consulted an attorney. B. CuRRAN \& F. SPALding, The Legal NeEDS OF THE PUBLIC 83 (1974). Four of the fifty-two tenants were found to be ineligible for service and were referred to private attorneys. Two other tenants came in with eviction notices but did not return with the summons and complaint. Nine tenants came in with the eviction notice and did return with the summons and complaint. Five appear to have come in after their default was taken.

81. In addition to the 52 tenants from the local branch, another 12 came to legal services with summons and complaints from other branches of the court. CAL. Civ. PROc. CoDE $\S 392$ (West 1973) allows filing of unlawful detainer actions within the county where the property is located. A motion may be made, based on CAL. CIV. PROC. CoDE § 395(c) (West 1973), to move cases to the "proper court for trial," but the attorneys settled these cases without attempting to move them. The figure of 58 was arrived at by subtracting the four ineligibles and two tenants who did not return with their summons and complaint from the total of 64 . See note 78 supra.

82. Three of the thirteen cases were from other branches of the court.

83. There is no reason to suspect that the same percentage does not hold for the group of 
ances as a function of total eviction actions, such appearances should be stated as a function of potential Green cases. When considered in this manner, this study suggests that Green defenses have been asserted by a much higher percentage of tenants to whom Green is applicable than has been assumed or reported previously.

The examination of the legal services files further disclosed that the issue of conditions was not limited to unlawful detainer actions. Forty-eight clients of the legal services office complained about the condition of their apartments. The clients had been served with an unlawful detainer complaint in only thirteen $(27 \%)$ of these cases. Fourteen $(29 \%)$ came to the office after they had been served with a three-day notice to pay or quit, ${ }^{84}$ and an additional twenty-one ( $44 \%$ ) clients came to the office without having been served a complaint or eviction notice to se what might be done to have their apartments repaired. ${ }^{85}$

\section{B. A Sense of Justice}

Those who believe that Green has had little impact not only question the amount of access to lawyers in low-income communities, but doubt that low-income people know of the warranty's existence. It is assumed that if one does not know the law, one will not seek legal redress of a violation of that law. This study confirms that there has been little diffusion of knowledge about the Green case, but shows a great deal of tenant activity nonetheless. Only two of the legal services clients who were imterviewed knew of or understood the legal implications of withholding rent. ${ }^{86}$ At the same time, almost all of them felt that withholding rent was the right thing to do if a landlord failed to maintain the property. ${ }^{87}$

all evicted tenants. The warranty tenants had approximately the same racial distribution as the low-income population. The percentage of tenants seen by legal services from buildings which appear deteriorating and dilapidated was $25 \%$, the same as the percentage seen of all tenants evicted. Six of those seen lived in deteriorating units and six lived in dilapidated units. The distribution of the cases was effected by the location of the office, but there is no reason to believe that this would effect the total. See note 98 infra.

84. Cal. CIV. Proc. CoDE $\S 1161$ (West 1972) provides for the three-day notice to pay or quit upon tenant's default.

85. The remainder of the noneviction cases were matters relating to security deposits (20\%), entry into public housing, old judgments, release of belongings, rent raises, discrimination, actions for rent only and other such problems. See also the nationwide survey reported by B. Curran \& F. Spalding, The Legal. Needs of the Public (1974) indicating that $12.2 \%$ of tenants with serious disputes with their landlords other than evictions saw an attorney. It is difficult to determine the number of potential warranty cases. During the study year, the 1974 special housing conditions census inventoried housing problems that would likely have effect on habitability, but in order for a problem to become a breach of the warranty, the landlord would have had to fail to repair the problem. BUREAU OF CENSUS, U.S. DEP'T. OF COMMERCE, Annual, Housing Survey: 1974, Housing Characteristics for Selected Metropolitan AREAS, SERIES H-170-74, 1976.

86. Four tenants were asked this question. One of the tenants who responded affirmatively was a tenant organizer and a friend of an attorney in the legal services office. The other was a very knowledgeable retired gentleman.

87. Asking about knowledge of the warranty proved difficult. Just as the tenants did not 
The tenants appeared to have a sense of justice independent of judicial interpretation of the landlord-tenant relationship. They viewed their landlord-tenant relationship as the more familiar contract relationship rather than in terms of the doctrines of covenants affecting real property interests. Thirty-five percent (17) of the warranty clients had withheld their rent in response to their landlord's refusal to make repairs and many others who had paid their rent during the warranty dispute had threatened to withhold. Furtherinore, the tenants who had discussed their warranty problems with relatives, neighbors, or friends usually were advised to take aggressive action against their landlords. ${ }^{88}$ In some cases, the tenants were advised to withhold or to repair and deduct. ${ }^{89}$

The extent to which this sense of justice existed in the study area is a question beyond the scope of this study. Although people who come to legal services offices are presumably among the most knowledgeable and aggressive, the legal services staff sensed a general rise in aggressiveness among low-income tenants in their area. They stated that five years ago tenants approached the office shyly and seemed to assume that nothing could be done on their behalf, but that more recently they came to the office assuming that they had rights of some sort.

This study does not show whether these tenants had an expanded sense of their rights or were simply more aggressive. ${ }^{90}$ It does show that Green, per se, had little role in the perceived change in attitude. Perhaps the many recent extensions of the rights of low income people have had a cumulative effect on the perceptions of the people in the community. It is also likely that the people in the study area have become more aggressive in response to the impact of the many social movements of the late 1960's and early 1970's. Although Green may be more a product of the people's sense of justice than the genesis of it, it is clear that a sense of justice is not enough. It is through the warranty doctrine, established in Green, that the popular sense of justice or general aggressiveness in seeking remedies will be given effect, if at all.

understand the lawyers, they did not understand the interviewers. Several forms of the question were tried. The one settled on was, "A recent Supreme Court decision said when a landlord rents an apartment it must be habitable and he must keep it up or you can go to court and have the rent reduced to the reasonable rental value. Have you heard of it?" No matter what form the question took, the answer was the same. Of necessity, the interviewers had to discuss the issue at length, and were instructed to probe the tenants on the issue. It was here that the tenants overwhelmingly expressed their agreement with the proposition that rent should be withheld, but they did not know anything about the law.

88. Nineteen of twenty-one tenants who were asked this question had talked about their problems with a friend (15), neighbor (19) and/or relative (14).

89. Fifteen were given aggressive advice: go to legal services (five); withhold (four); fight (four); repair and deduct (one); see a lawyer or go to legislator's office (one). Four were advised to move and avoid the bother of complaining and two were not given advice.

90. The expectancy was not universal. One middle-aged client had disregarded a younger neighbor's advice to withhold rent, believing that it was improper. Since he felt that there was not much one could do if a landlord refused to repair an apartment, he resigned himself to the situation by saying that some landlords are good and some are not-his last landlord was good and he guessed this one was not. 


\section{Problems of Implementation}

The proponents and opponents of Green, in analyzing the likely impact of the warranty, assume substantial implementation of the law. Beyond the questions raised in the San Francisco study, this study has disclosed six factors limiting the enforcement of the warranty. The first among these was the perceived hostility of the local branch of the municipal court. Second, the lawyers responded to their perception of the court's attitude with a conservative interpretation and application of the law. Third, the lawyers were overworked and not fully prepared to exploit the case's potential. Fourth, the language of the Green decision is ambiguous, making it difficult for lawyers to explain the law to their clients and to enforce it according to their clients' desires. Fifth, the clients had a variety of problems that limited their ability to engage in and sustain litigation. Last, the tenant unions, which the proponents expected to expand the use of Green, did not materialize.

\section{Problems with the Court}

Green's application to the problems of low-income tenants depends on the interpretation given to key phrases of the opinion by local judges. What constitutes a "material breach" of the warranty? What "materially affects health and safety?" What is the "reasonable rental value?"91 A judge who interprets these phrases narrowly can make successul litigation nearly impossible. This was the situation in the study area, according to the legal services attorney's. Before the commencement of this study, cases advancing the Green defense were litigated and lost in the branch of the municipal court that serves the study area. The legal services attorneys concluded that further litigation in that particular court would be a waste of time. As a result, their emphasis shifted almost entirely to using the warranty to negotiate settlements of landlord-tenant disputes.

During the study year, the warranty became an issue in thirteen unlawful detainer actions. All were settled. In twelve cases the tenant moved as part of the settlement, but the tenants were usually allowed up to a month's free rent to find a new home, and one tenant received $\$ 400.00$ in settlement of a claim for retroactive rent abatement. ${ }^{92}$ In the one case where the tenant remained in possession, she made a partial payment of the disputed rent; she had used the remainder of her rent to make repairs to the property. A comparison of these cases to the other unlawful detainer cases handled by the legal services office indicates that the major benefit to the tenant of the use of the warranty was an increased probability that the landlord would waive claims for unpaid rent. A quarter of the unlawful detainer cases

91. For a discussion of the legal issues involved in the interpretation of these phrases, see Moskovitz, supra note 7.

92. See Quevedo v. Braga, 72 Cal. App. 3d Supp. 1, 140 Cal. Rptr. 143 (Super. Ct. 1977). 
handled by legal services attorneys where the warranty was not an issue resulted in judgments against the tenant giving the landlord possession and an award for rent due..$^{93}$

If a case could not be settled without filing a responsive pleading, the legal services attorneys were inclined to file a motion to strike or a demurrer rather than an answer. Their purpose in doing so was not to engage in the protracted litigation that is feared by those who oppose the warranty, but to escape the local municipal court. They perceived the law and motion judge who sat in the main branch of the court to be more sympathetic to the warranty. He usually sustained their motions and demurrers, relying on the theory that Green obliged the landlord to affirmatively plead the absence of violations of the housing code that materially affect health and safety. In this jurisdiction, these were known as Green demurrers. ${ }^{94}$

The attitude of the local judiciary led the legal services attorneys to interpret Green conservatively. One attorney, for example, believed that opportunities to use the warranty in litigation were infrequent because tenants rarely gave written notice of their complaints or their intention to withhold. When told that Green did not require notice in writing, ${ }^{95}$ he stated that this may be true in theory, but not with the local judiciary. Further, while the language of Green does not relate the repair-and-deduct statute to the warranty, the legal services attorneys clearly made this connection. They believed that a tenant should exhaust the repair-and-deduct remedy before employing the warranty. ${ }^{96}$ As a result of this approach, the nine tenant rent strike discussed earlier was conducted under the repair-and-deduct statutes by pooling the inoney withheld in order to inake repairs.

There is evidence that the problem with the court in the study area is not unusual. Interviews with thirteen judges in the San Francisco-Oakland area indicated that these judges were also likely to interpret Green narrowly. ${ }^{97}$ In general, they saw the warranty problem as one of tenants without

93. Of the 46 cases handled in the local branch, 36 were not warranty cases: abandoned, $10(28 \%)$; possession only, $9(25 \%)$; possession and damages, $9(25 \%)$; dismissed with prejudice, $5(14 \%)$; dismissed without prejudice, $2(6 \%)$; tenant retained possession with payment schedule, $1(3 \%)$.

94. The legal services lawyers argued that because Green extended contract principles to the landlord-tenant relationship, an action in unlawful detainer for failure to pay rent should be seen as an action for rescision and for damages. Relying on CAL. Civ. Proc. CODE $\S 459$ (West 1973), they contended a landlord must plead that he has performed all conditions on his part including maintaining the property in a habitable condition.

95. For a discussion of this issue, see Moskovitz, supra note 7, at 1462 . Although it is a good idea to give written notice, no authority requires it.

96. See note 58 supra. In Green, the landlord had argued that the repair-and-deduct remedy was exclusive. The court held that it was not, and that the common law warranty existed independent of the statute. Green v. Superior Court, $10 \mathrm{Cal}$. 3d 616, 629-31, 517 P.2d 1168, 1176-78, 111 Cal. Rptr. 704, 712-14 (1974). The court, in note 23, further indicated the independence of the remedies by suggesting that "the standard of 'tenantability' set out in Civil Code section 1941.1 though not strictly applicable" may help define habitability. There was no indication that the exhaustion of either remedy effects the other.

97. Atlas, Atlas \& Pransky, Ignorance of the Law Is No Excuse, SHELTERFORCE, Winter 1977 , at 8-9. 
funds to pay rents and landlords without funds to make repairs. They considered judicial intervention to be improper under those circumstances. This study has shown that tenants and landlords who become involved in warranty disputes do not necessarily fit this stereotype. For the most part, tenants pay their rent or withhold it in good faith and landlords have the ability to make the requested repairs.

\section{Problems with Legal Services}

This study finds that access to attorneys is greater than previously reported. Further, access appears to be increasing along with the upsurge in the use of legal services programs. ${ }^{98}$ New clients were learning of the existence of the office and using it. This is evidenced by the fact that only a quarter of the warranty clients had been clients of the legal services office prior to the current warranty dispute. ${ }^{99}$ Table 10 lists the agencies that referred warranty clients to legal services. However, as use of legal services increases there is less time for each client. In addition to the local court's resistance to Green, the level of intake generated pressure within legal services to settle each case as quickly as possible. This pressure reduced the incentive to explore the warranty possibilities of the office's many other cases.

Table 10

Agencies which Referred Warranty Clients to Legal Services

\begin{tabular}{lc} 
Referral Agency & No. \\
\hline Prior client & 9 \\
Public-private agency: & \\
$\quad$ Neighborhood Adults Ac- & \\
$\quad$ tion Project & 9 \\
Health Department & 3 \\
Welfare Department & 3 \\
Marshall & 1 \\
Court & 1 \\
Better Business Bureau & 1 \\
Senior Citizens Club & 1 \\
Publicity & 3 \\
Friends & 3 \\
Knew someone in office & 2 \\
Couldn't specify & 2 \\
\hline
\end{tabular}

98. Access was not uniform over the study area. Those closer to the office used it more than others. Twenty-one percent (44) of the evicted tenants seen in the local branch lived within a mile of the legal services office. Thirty-one percent (18) of the tenants who legal services represented in unlawful detainer actions lived within the same distance.

99. This confirms findings made by other researchers that low income tenants depend on formal contacts to find a lawyer more than higher income groups who rely on informal contacts with friends and family. Ladinsky, The Traffic in Legal Services 11 LAw \& Soc'y 207, 219 (1976). From legal services' viewpoint, it is encouraging that its formal network is broad, but disappointing that an office which has been in the area for ten years must still rely on such a formal network.

100. Ten legal services files did not contain this information. 
Primary among the other factors that constrained the application of the warranty was the narrowly legalistic approach that most of the lawyers in the office took to the use of Green. The case expresses a policy of encouraging repair of rental property, as well as a rule of law. However, most of the legal services attorneys used it primarily as a defense to unlawful detainer actions. For example, most referred clients to a code enforcement agency to prepare their case rather than to obtam repairs. The lawyers made no follow-up on the referrals to determine whether repairs had been made. In most instances, settlements which resulted in the client moving did not include a condition that the property be repaired.

In many of the cases studied, the lawyer's decision to focus on the individual case rather than the broad policy of Green may have appeared to coincide with the tenant's immediate imterests. In light of the decreasing time available to prepare any one case in the constantly increasing legal services caseload and the unfavorable attitude of the local division of the inunicipal court toward the Green defense, an expedient settlement in which the tenant got at least something may have appeared to be the tenant's best alternative. Before accepting this conclusion, however, one should consider that the local mumcipal court could have been avoided by demanding a jury trial. Such a demand would have transferred the case to the main branch of the court, where some of the judges were thought to be more sympathetic to the warranty. Moreover, a jury might also have been more sympathetic. In this way, the attorneys could have both pursued the implementation of the Green policy and obtained greater satisfaction of the tenant's interests than was available through expedient settlement. Besides feeling the pressure of a heavy case load, however, the legal services attorneys were young and without jury trial experience, and felt reluctant to venture into this dimension of legal practice.

Finally, it was not clear that all tenants were satisfied with the lawyers' efforts. It is difficult to determine in practice what adequate representation is. ${ }^{101}$ Should the satisfaction of tenants be the rule or should some other professional standard be applied? While the majority of tenants interviewed were satisfied with their representation, there are indications that those who moved (this group is underrepresented in the interview sample ${ }^{102}$ ) were resentful. Table 11 analyzes the relation between the results of the tenants' cases and their satisfaction with legal services. The tenants experienced moving as a social and fimancial burden and most of those who chose to remain in the subject property did so to avoid this burden. ${ }^{103}$ Tenant

101. See Rosenthal, Evaluating the Competence of Lawyers, 11 LAW \& Soc'y 257 (1976).

102. Ten $(40 \%)$ of those interviewed moved as part of the settlement of the dispute. Fifteen (60\%) did not move, although three of them were members of the nine-tenant rent strike who moved soon after. If these tenants are counted among those who moved, $52 \%$ moved and $48 \%$ stayed. See note 56 supra, for figures on all warranty tenants.

103. Eight tenants were asked this question; all stated that moving was inconvenient. Four lost work, two had to pay for the rent of a truck, five lost contact with friends and two felt that it was difficult for their children to adjust. For a discussion of the potential impact of moving, 
satisfaction is the proper measure of counsel's quality only if the clients have been well informed about their options. The vague language of the Green decision made it difficult for lawyers to communicate with their clients.

Table 11

Relation of Result of Case to Satisfaction with Legal Services Satisfaction with Legal Services

\begin{tabular}{lrccc} 
Results of Case & & Satisfied & Mixed & Unsatisfied \\
\hline $\begin{array}{c}\text { Repaired: } \\
\begin{array}{c}\text { Possession } \\
\text { maintained }\end{array}\end{array}$ & 14 & 12 & & \\
$\begin{array}{c}\text { Decided to move } \\
\begin{array}{c}\text { oot extension to } \\
\text { move }\end{array}\end{array}$ & 3 & 2 & 0 & 1 \\
$\begin{array}{c}\text { Received eviction notice } \\
\text { \& moved }\end{array}$ & 2 & 1 & 0 & 1 \\
$\begin{array}{c}\text { Forcibly evicted, reentered } \\
\text { and then moved }\end{array}$ & 1 & 0 & 0 & 1 \\
& $\frac{1}{21^{104}}$ & $\frac{0}{15}$ & $\frac{0}{1}$ & 1
\end{tabular}

\section{Problems with the Law}

The legal services attorneys though it important that their clients understand the law, but had a great deal of difficulty conveying its meaning. One case involved a tenant who had paid her $\$ 150.00$ rent for a month in which she went without hot water although she repeatedly demanded that her landlord remedy the problem. After the landlord made the requested repairs, she sent him a note explaining that she was keeping $\$ 50.00$ of her next month's rent money for the inconvenience she had suffered. ${ }^{105}$ When the landlord objected and demanded the $\$ 50.00$, the tenant went to legal services. In an effort to educate the client about the law, her lawyer explained both the repair-and-deduct remedy and the warranty in detail. According to the attorney's notes, he finally advised the client to tell her landlord that she had paid the "reasonable rental value" required by the law and to return if the landlord attempted to evict her. The client did not return. When a member of the research team interviewed her later, she explained

see Fried, Grieving for a Lost Home, The URBan Condinon (L. Duhl ed. 1963). Those who did not move gave the following reasons for not moving: likes neighbors; near places to go; costs money to move, hates to move; not in best of health; moving difficult; looking, but a new place hard to find; problem not serious enough; put a lot of work in place; did not want to give in in the middle of a fight.

104. Three people were not asked these questions; one interview was broken off before these questions were reached.

105. This tenant's position on how much rent she should pay was consistent with Moskovitz's proposal for determining reasonable rental value. See Moskovitz, supra note 7, at 1458-64. If the ability of the public to understand the law is a factor that should be considered in establishing legal principles, this would seem to indicate using "inconvenience" as the phrase which sets the standard for reduction in rental value. 
that she had paid the $\$ 50.00$ to her landlord as the lawyer had told her to do.

This case could be seen as an isolated extreme if it were not for the general lack of knowledge of the warranty among clients. ${ }^{106}$ Part of the problem seemed to be that the attorneys felt compelled to explain the law fully. ${ }^{107}$ They explained the details of both the repair-and-deduct remedy and the warranty whether or not both were relevant to the issue at hand. The clients did not seem able to absorb and differentiate both doctrines. Because the explanation of the repair-and-deduct remedy preceded that of the warranty, the explanation of the warranty often produced no clear understanding of its meaning. This is supported by the finding that nearly half the interviewees were aware of the repair-and-deduct remedy. ${ }^{108}$

The attorneys did not rely entirely on verbal explanations of the law. They prepared a one-page written explanation of the repair and deduct remedy, the warranty, and the protection against retaliation. This effort did not solve the problem. The client whose story is told above received one of these sheets, but since she believed that she understood the law, she did not read it. Another client purchased a copy of the California Tenants' Handbook, ${ }^{109}$ which contains an explanation of the warranty, but she too remained unenlightened.

Most of the tenants believed that they should not pay their rent if a landlord failed to maintain the leased premises, but they had difficulty understanding concepts such as "materially affect health and safety" and "reasonable rental value." Since legal scholars have questioned the ability of the trial courts to interpret these concepts, ${ }^{110}$ it should not be a surprise that the layman also has had trouble.

Green presents an additional difficulty in that it does not define a standard of repair or encompass aesthetic concerns. ${ }^{111}$ While at least $80 \%$ of the property in the study was repaired, these repairs were of varying quality. The difficulties created by this omission are illustrated by problems that led to the disintegration of the mine tenants rent strike mentioned earlier. In this case, the landlord made repairs that returned the property to a habitable state, but not to its original condition. For example, instead of replacing a

106. Only two of the tenants interviewed understood the legal implications of withholding rent. See note 84 supra.

107. The lawyers were very concerned about tenants not fully understanding the law; they feared that a tenant might act on partial information and be evicted as a result. This fear was heightened by the attitude of the local court. The lawyers insisted that the interviewers warn the tenants that use of the warranty was complex and that they should seek legal help if they wanted to use it.

108. Eleven of the twenty-four tenants interviewed knew of the repair-and-deduct remedy. See note 62 supra.

109. M. Moskovitz, R. Warner, \& C. Sherman, California Tenants' Handbook (edition unknown, 1972). All the editions speak of the warranty of habitability although the first edition cites Hinson v. Delis, 26 Cal. App. 3d 62, 102 Cal. Rtpr. 661 (1st Dist. 1972).

110. E.g., Green Hope, supra note 16, at 756-57, 764-66.

111. 10 Cal.3d at 637, 517 P.2d at 1182-83, 111 Cal. Rptr, at 719-20. 
damaged door, he nailed a piece of plywood over the break. The repair made the door functional, but was not adequate from the tenants' point of view. In effect, it was a daily reminder that the property they lived in had now become a slum. The attorney handling the strike thought there was nothing he could do to ameliorate this problem; the tenants felt they had been betrayed. As one tenant put it, "the landlord was getting away with murder."

\section{Problems with the Clients}

The life style of the legal services clients added to the other problems of implementing the law reform. Three examples were found: the presence of foreign nationals without documents, personal problems of clients that interfered with the process of disputes, and the disappearance of clients in the midst of preparations for litigation. Two of these problems emerged in the nine tenant rent strike.

Two of the tenants who joined the strike were foreign nationals without documents. Members of the legal services staff believed that it was common for problem landlords to rent to such tenants because, as a rule, they did not make "trouble." The landlord in this case was aware of the immigrant status of his tenants and threatened to call the Immigration Service. This threat became a factor in the negotiations that led to settlement of the strike. Two other tenants, both leaders of the strike, had personal matters that caused them to lose interest in pursuing the strike. One became involved in a divorce and the other went to the hospital to deliver a child.

The transience of the tenants was demonstrated in a case in which an answer and cross-complaint for retroactive rent abatement were filed. When the judge found the cross-complaint to be improper, ${ }^{112}$ the attorney decided to file an affirmative action for the tenant's back rent, instead of appealing the dismissal of the cross-complaint. On attempting to contact his client so that she could sign an application to file in forma pauperis, he found that she had moved without leaving a forwarding address. He had no choice but to abandon the litigation.

\section{Problems with the Formation of Tenant Unions}

Its proponents claim that Green will lead to the formation of tenant unions. Following on the assumption that the warranty problem is pervasive, it is argued that tenants will jom together to use the threat or power of all of a landlord's tenants withholding rent to obtain repairs. It is anticipated that, having recognized the potential of their collective power, the tenants will form permanent organizations, tenant unions. These unions would, either during or after a rent strike, attempt to deal collectively with the landlord on all matters in a relationship similar to that between an employer

112. Green Hope, supra note 16 , at $729,747-48$. 
and a labor union. Once such organizations were formed, they would begin to help organize other tenants. Over time they would change the nature of the landlord-tenant relationship. The findings of this study are that collective rent strikes occurred, and repairs were made, but there was no movement toward the formation of tenant unions.

The legal services lawyers recognized the potential in collective rent strikes and tenant unions and wanted to encourage such activities where appropriate. However, because they were overwhelmed with the continual intake of clients, they decided to use the tool selectively against landlords who seemed to be repeated violators of the warranty and other landlordtenant laws. Identification of such landlords was one of the topics discussed at their weekly staff meetings. Ten such landlords had been identified. Even regarding these landlords, the lawyers did not actually intend to organize; rather, they intended to suggest the possibility of collective action to the clients and to support any efforts at organization. Two instances of collective rent strikes occured during the study period. ${ }^{113}$ The nine tenants rent strike against the large speculator, discussed in previous sections, illustrates the problems that can arise to prevent the translation of a rent strike into a tenant union.

A rent strike can be a vehicle toward the formation of a tenant union or it can be a dramatic drain on tenants' energy even if it is successful in obtaining repairs. ${ }^{114}$ The nine tenants rent strike is an example of the latter case. In addition to the tenants' personal difficulties and displeasure with the quality of repairs, the situation was further complicated by the role played by the lawyer handling the strike. According to the literature on the subject, ${ }^{115}$ an attorney becoming involved in tenant organizing must avoid conflicts of interest between tenants and not become a leader of the strike. In this instance, the lawyer violated both rules.

The primary problem in the lawyer's effort was that he assumed leadership of the strike. He became the head negotiator, collected and escrowed the rent, and planned to act as general contractor should tenant initiated repairs become necessary. He did this because other experiences with this landlord convinced him that the landlord was apt to take retaliatory action against the strike leaders. ${ }^{116}$ The conflict of interest problem arose when the landlord threatened to report two tenants who were foreign nationals without documents. The lawyer stated that he felt caught between the interests of these two tenants and the others and that he felt pressure to settle

113. The other strike involved only two of five tenants. It ended successfully with the tenants remaining in possession of their apartments.

114. Burghart, Building a Tenant Union, SHelterforCE, Fall, 1976, at 12.

115. Atlas, Lawyer's Role in Organizing, SHelterForCE, November, 1975, at 6, 15.

116. The large speculator was also the defendant in the only affirmative action filed by the legal service attorneys. In this suit filed in the superior court the landlord stipulated to an order enjoining him from further forcible evictions, seizing tenants' property, interrupting utilities, using improper notices and retaliation. 
the strike. The second problem resulted from the tenant dissatisfaction with the quality of the landlord's repairs. The attorney as head negotiator, rent collector and escrow officer became the focus of some of the tenants' dissatisfaction. This dissatisfaction, added to the other problems, broke the tenants' will to continue and within two months all the striking tenants had left the building.

\section{CONCLUSION}

The goal of this research was the generation of grounded hypotheses that might be the foundation for additional research in this area of law and policy. A number of such hypotheses might be formulated from the findings reported in this Article, but ten emerge as most significant:

1) Green is being employed more often and violations of the warranty occur less often than assumed.

2) Most of the Califormia low-income housing stock is in decline and economically repairable as opposed to decayed and economically unrepairable.

3) The use of the warranty does not affect the housing market.

4) The warranty is leading to the repair of property and could assist code enforcement if knowledge of it spreads.

5) Tenants who remain in possession do not have their rents substantially raised.

6) Few tenants who do not seek the aid of an attorney before the eviction process has begun remain in possession at the conclusion of the dispute.

7) While aggressive tenants act in ways consistent with the warranty and bring their cases to legal services, serious problems stand in the way of diffusing knowledge of the law.

8) Because of judicial hostility to warranty cases, tenants incur the social and economic cost of moving, landlords lose the partial rent envisioned in the Green decision and the ambiguity in the language of the decision is not being clarified.

9) Most tenants or their lawyers are not inclined to abuse the law.

10) While rent strikes are taking place, there is little movement toward tenant union formation.

If research were to stop at this point, the findings of this study would testify to the wisdom of the policy adopted by the California Supreme Court. At the same time it would have to be concluded that the legal services system has encountered formidable problems attempting to apply this reform in the law. The warranty demonstrated that it can contribute to a reduction of the sort of neglect of property which could take California's housing stock from declime to decay. It remains to be seen, however, 
whether the problems of implementing this reform in the law can be overcome so that it will not be said of future application of the law, as was said of landlord-tenant decisions prior to 1872 , "[T] cannot understand their justice, or even realize their existence." 117

117. Annotation to CAL. Civ. Code $\$ 1941$ (Croker 1872). 